\title{
Knockout Mice Reveal Opposite Roles for Serotonin 1A and 1B Receptors in Prepulse Inhibition
}

Stephanie C. Dulawa, M.S., Cornelius Gross, Ph.D., Kimberly L. Stark, M.S., Rene Hen, Ph.D., and Mark A. Geyer, Ph.D.

The serotonergic system is involved in the modulation of prepulse inhibition (PPI) and habituation of startle, which are deficient in schizophrenia patients. PPI is the reduction in startle amplitude that occurs when a weak "prepulse" precedes a startling stimulus by 30-500 msec. The roles of 5- $\mathrm{HT}_{1 \mathrm{~A}}$ and $5-H T_{1 B}$ receptors in modulating PPI and habituation were examined using wild-type (WT), 5-HT $\mathrm{T}_{1 A}$ knockout (1AKO), and 5-HT $T_{1 B}$ knockout (1BKO) mice. The 5-HT $\mathrm{T}_{1 \mathrm{~A} / 1 \mathrm{~B}}$ agonist RU24969 reduced PPI and habituation in WT and $1 A K O$, but not $1 B K O$ mice, whereas the $5-H T_{1 A}$ agonist $8-O H-D P A T$ increased PPI in WT and $1 B K O$, but not in $1 A K O$ mice. Similarly, the selective $5-H T_{1 B}$ agonist anpirtoline reduced PPI in WT, but not in $1 B K O$ mice. In experiments using intact $129 \mathrm{~Sv}$ mice, the $5-\mathrm{HT}_{1 A}$ agonist flesinoxan increased PPI while anpirtoline decreased PPI and habituation. Findings suggest that $5-\mathrm{HT}_{1 B}$ receptor activation decreases PPI and habituation, and 5-HT $\mathrm{T}_{1 \mathrm{~A}}$ receptor activation increases PPI in mice. [Neuropsychopharmacology 22:650-659, 2000] (C) 2000 American College of Neuropsychopharmacology. Published by Elsevier Science Inc.
KEY WORDS: Sensorimotor gating; Startle habituation; Anpirtoline; 8-OH-DPAT; Flesinoxan; RU 24969

Sensorimotor gating is a form of central nervous system inhibition that "gates" or filters out excessive sensory, motor, and cognitive information to sustain mental and behavioral integration. Prepulse inhibition (PPI), an operational measure of sensorimotor gating, is the reduction in startle amplitude that results when an abrupt startling stimulus is preceded $30-500 \mathrm{msec}$ by a nonstartling prepulse (Graham 1975). Patients with several neuropsychiatric disorders, including schizophrenia (Braff et al. 1978, 1992; Bolino et al. 1994), schizotypal

From the Department of Neuroscience (SCD, MAG), and Department of Psychiatry (MAG), University of California at San Diego, La Jolla, CA; and Center for Neurobiology and Behavior, Columbia University, New York, NY (CG, KLS, RH).

Address correspondence to: Mark A. Geyer, Ph.D., Department of Psychiatry, University of California at San Diego, 9500 Gilman Drive, La Jolla, CA 92093-0804.

Received August 27, 1999; revised November 29, 1999; accepted December 6, 1999. personality disorder (Cadenhead et al. 1993), and obsessive compulsive disorder (Swerdlow 1995) exhibit PPI deficits. Startle habituation, a simple form of learning, which refers to the decrement in startle responding to repeated presentations of an initially novel and intense stimulus (Thorpe 1956), is also deficient in schizophrenia and schizotypal patients (Braff et al. 1992; Cadenhead et al. 1993; Geyer and Braff 1982; Bolino et al. 1994). Further investigation of the neural substrates modulating PPI may provide insight into the pathophysiology of the sensorimotor gating deficits in these syndromes.

Serotonin $_{1 \mathrm{~A}}\left(5-\mathrm{HT}_{1 \mathrm{~A}}\right)$ and $\operatorname{serotonin}_{1 \mathrm{~B}}\left(5-\mathrm{HT}_{1 \mathrm{~B}}\right)$ receptors have been suggested to contribute to the modulation of PPI. For instance, the $5-\mathrm{HT}_{1 \mathrm{~A}}$ agonist $8-\mathrm{OH}-$ DPAT decreases PPI in rats (Rigdon and Weatherspoon 1992; Sipes and Geyer 1995), but increases PPI in mice (Dulawa et al. 1997, 1998). However, 8-OH-DPAT also has affinity for 5- $\mathrm{HT}_{7}$ receptors (Tsou et al. 1994; Ying and Rusak 1997). The 5- $\mathrm{HT}_{1 \mathrm{~A} / 1 \mathrm{~B}}$ agonist RU24969 decreases PPI and habituation in wild-type (WT), but not 
5-HT ${ }_{1 \mathrm{~B}}$ knockout (1BKO) mice (Dulawa et al. 1997), suggesting that $5-\mathrm{HT}_{1 \mathrm{~B}}$ receptors modulate both forms of startle plasticity in mice.

The recent availability of $5-\mathrm{HT}_{1 \mathrm{~A}}$ knockout (1AKO) mice (Ramboz et al. 1998; Heisler et al. 1998; Parks et al. 1998) and the selective $5-\mathrm{HT}_{1 \mathrm{~B}}$ agonist anpirtoline (Schlicker et al. 1992) permits more precise dissection of the roles of 5- $\mathrm{HT}_{1 \mathrm{~A}}$ and $5-\mathrm{HT}_{1 \mathrm{~B}}$ receptors in behaviors of interest. 5- $\mathrm{HT}_{1 \mathrm{~A}}$ receptors are autoreceptors and heteroreceptors for serotonergic and nonserotonergic neurons and are located on cell bodies and dendrites, where they inhibit cell firing (Hamon et al. 1990). $5-\mathrm{HT}_{1 \mathrm{~B}}$ receptors are autoreceptors and heteroreceptors expressed on axon terminals that inhibit neurotransmitter release (Boschert et al. 1994; Hen 1992). The densest localization of $5-\mathrm{HT}_{1 \mathrm{~A}}$ receptors is in the hippocampus, dorsal raphe, interpeduncular nucleus, and lateral septum (Ramboz et al. 1998). $5-\mathrm{HT}_{1 \mathrm{~B}}$ receptors are most densely localized on striatal neuron terminals in the globus pallidus and substantia nigra, and on Purkinje neuron terminals in the deep cerebellar nuclei (Boschert et al. 1994; Pazos et al. 1988). Many of these brain regions, such as the hippocampus (Caine et al. 1991), septum (Koch 1996), raphe (Sipes and Geyer 1995), and ventral pallidum (Swerdlow et al. 1990, 1992; Sipes and Geyer 1997), are components of the neural circuitry involved in modulating PPI.

We assessed the roles of $5-\mathrm{HT}_{1 \mathrm{~A}}$ and $5-\mathrm{HT}_{1 \mathrm{~B}}$ receptors in modulating PPI and habituation using WT, $1 \mathrm{AKO}$, and $1 \mathrm{BKO}$ mice, which are without any obvious anatomical or behavioral abnormalities (Ramboz et al. 1998; Saudou et al. 1994). WT, 1AKO, and 1BKO mice received saline, the $5-\mathrm{HT}_{1 \mathrm{~A} / 1 \mathrm{~B}}$ agonist $\mathrm{RU} 24969$, which binds preferentially at $5-\mathrm{HT}_{1 \mathrm{~B}}$ sites (Sills et al. 1984; Doods et al. 1985), and the 5-HT $\mathrm{HA}_{1 \mathrm{~A}}$ agonist 8-OH-DPAT. Then, the selective 5- $\mathrm{HT}_{1 \mathrm{~A}}$ agonist flesinoxan (Leishman et al. 1994; Schoeffter and Hoyer 1988) was tested in intact 129Sv mice to confirm the PPI-increasing effects of 8-OH-DPAT. Lastly, we assessed whether anpirtoline would disrupt PPI more robustly than RU24969 due to the selectivity of anpirtoline for $5-\mathrm{HT}_{1 \mathrm{~B}}$ and not $5-\mathrm{HT}_{1 \mathrm{~A}}$ receptors (Schlicker et al. 1992). Therefore, a dose response study of anpirtoline was conducted with intact 129Sv mice, and the optimal dose for PPI disruption was then tested in WT and 1BKO mice.

\section{MATERIALS AND METHODS}

\section{Subjects}

For all experiments, WT and knockout mice were females on a pure 129Sv background (for details, see Phillips et al. 1999) received from the laboratory of Dr. Rene Hen, Columbia University, New York, NY. WT and knockout mice were the offspring of either heterozy- gote breeders or homozygote breeders no more than three generations removed from a heterozygote cross.

For Experiment 1, ten WT, fifteen $1 \mathrm{BKO}$, and ten 1AKO mice 16-18 weeks old and weighing 15-27 g were the subjects. For Experiment 2, twenty-four female 129SvEms ${ }^{-+T e r}$ ? $/ \mathrm{J}$ mice (Jackson Labs, Bar Harbor, Maine) 10-12 weeks old were the subjects (14-21 g). For Experiment 3, thirty female $129 \mathrm{SvEms}{ }^{-+T e r}$ ? $/ \mathrm{J}$ mice (Jackson Labs, Bar Harbor, Maine) 7-9 weeks of age were the subjects (13-20 g). For Experiment 4, ten WT and ten $1 \mathrm{BKO}$ female mice $16-18$ weeks old were the subjects (17-25 g).

Mice were housed in groups of four with same-type mice in a vivarium with a $12 \mathrm{~L}: 12 \mathrm{D}$ schedule (lights off at $0900 \mathrm{~h}$ ). Food and water were available ad libitum. Testing occurred during the dark phase and was in accord with the "Principles of laboratory animal care" $\mathrm{NIH}$ guidelines and with local animal care committee approval.

\section{Drugs}

5-methoxy-3(1,2,3,6)tetrahydropyridin-4-yl-1H-indole (RU24969) was provided by Roussel UCLAF (Romainville, Cedex, France). The 8-hydroxy-2(di- $n$-propylamino)-tetralin (8-OH-DPAT) was obtained from Research Biochemicals (Natick, MA). Flesinoxan was provided by Solvay Pharma (Weesp, The Netherlands). The 6-chloro-2-(piperidyl-4-thio)-pyridine (anpirtoline hydrochloride) was purchased from Tocris Cookson (Ballwin, MO). All compounds were made fresh daily and dissolved in $0.9 \%$ saline as salt doses, except for flesinoxan, which was dissolved in distilled water.

\section{Injections}

Injections were given with $0.5 \mathrm{cc}$ insulin syringes and 28 gauge needles. Solutions were prepared at a volume of 5 $\mathrm{ml} / \mathrm{kg}$ bodyweight. RU24969 was administered intraperitoneally (i.p.); 8-OH-DPAT, anpirtoline, and flesinoxan were administered subcutaneously (s.c.). Saline or distilled water was administered i.p. or s.c., as appropriate.

\section{Apparatus}

Each startle chamber consisted of a nonrestrictive Plexiglas cylinder $5 \mathrm{~cm}$ in diameter, resting on a Plexiglas platform in a ventilated chamber (San Diego Instruments, San Diego, CA). A high-frequency speaker mounted $33 \mathrm{~cm}$ above the cylinder produced all acoustic stimuli. Mouse movements were detected and transduced by a piezoelectric accelerometer located under the cylinder, and then digitized and stored by a computer and interface assembly. Sixty-five 1-msec readings were recorded to obtain the amplitude of the ani- 
mals' startle response to each stimulus, beginning at startling stimulus onset. Sound levels were measured as described elsewhere (Mansbach et al. 1988) using the A weighting scale.

\section{Test Session}

Mice were exposed to five different types of discrete stimuli or "trials": a 40-msec broadband $120 \mathrm{~dB}$ burst (Pulse Alone trial); three different Prepulse + Pulse trials in which either 20-msec long $3 \mathrm{~dB}, 6 \mathrm{~dB}$, or $12 \mathrm{~dB}$ above background stimuli preceded the $120 \mathrm{~dB}$ pulse by $100 \mathrm{msec}$ (onset to onset); and a No Stimulus trial, in which only the background noise was presented. Trials were presented in a pseudo-random order, separated by an average of $15 \mathrm{~s}$ (range: 7-23 s). The test session began with a 5-min acclimation period, followed by four consecutive blocks of test trials. Blocks one and four consisted of six consecutive Pulse Alone trials, while blocks two and three each contained six Pulse Alone trials, five of each kind of Prepulse + Pulse trials, and five No Stimulus trials. Thus, the entire 22-min session consisted of 62 test trials.

\section{Behavioral Testing}

Experiment 1. WT, $1 \mathrm{BKO}$, and $1 \mathrm{AKO}$ mice were tested in the startle session on three different test days in a within-subjects design, with one rest day separating each test day. Each animal received saline, $10 \mathrm{mg} / \mathrm{kg}$ RU24969, and $5 \mathrm{mg} / \mathrm{kg} 8-\mathrm{OH}-\mathrm{DPAT}$ in a counterbalanced order. Although both RU24969 and 8-OH-DPAT have similar effects on PPI at lower doses, the present doses affect PPI more reliably (Dulawa et al. 1997). Animals were placed into testing chambers $30 \mathrm{~min}$ after injection.

Experiment 2. Mice received either 0, 0.1, 1, or $10 \mathrm{mg} /$ $\mathrm{kg}$ flesinoxan in a between-subjects design. Animals received injections $30 \mathrm{~min}$ before startle testing.

Experiment 3. Mice received either 0, 5, or $10 \mathrm{mg} / \mathrm{kg}$ anpirtoline in a between-subjects design, $15 \mathrm{~min}$ before startle testing.

Experiment 4. WT and 1BKO mice received either saline or $5 \mathrm{mg} / \mathrm{kg}$ anpirtoline in a between-subjects design, $15 \mathrm{~min}$ before startle testing. The $5 \mathrm{mg} / \mathrm{kg}$ dose of anpirtoline was selected based on the results of Experiment 3.

\section{Data Analyses}

PPI was calculated as [100 - (prepulse-Pulse trial / Pulse Alone) $\times 100$ ]. Pulse Alone trials in this calculation were the averaged Pulse Alone values for blocks 2 and 3. Large PPI values indicate substantial inhibition of the startle response by the prepulse, whereas small
PPI values indicate little inhibition of the startle response by the prepulse. When an ANOVA assessing PPI yielded no interaction including all factors, data were collapsed for prepulse intensity to reduce the number of post-hoc ANOVAs required for Experiment 1, and to avoid loss of power.

Two different startle reactivity measures were assessed: 1) initial startle reactivity in block 1 ; and 2) averaged blocks 2 and 3 startle reactivity, which is used for the calculation of PPI. Block 1 startle reactivity was analyzed to evaluate potential phenotypic differences and drug effects on startle reactivity, while avoiding the confounding effects of habituation. Averaged blocks 2 and 3 startle reactivity was assessed to evaluate potential confounds in the calculation of PPI. Startle habituation was assessed as the average startle reactivity to Pulse Alone trials across 4 blocks. In addition, bodyweights of $\mathrm{WT}, 1 \mathrm{AKO}$, and $1 \mathrm{BKO}$ mice were compared using ANOVA.

For Experiment 1, analysis began with four separate ANOVAs for each measure (startle, PPI, habituation). Each ANOVA compared the effects of saline and one drug on WT mice and one kind of knockout mouse: (WT, 1BKO, saline, RU24969); (WT, 1BKO, saline, 8-OHDPAT); (WT, 1AKO, saline, RU24969); and (WT, 1AKO, saline, 8-OH-DPAT). Alpha was set at $p<.05$. Significant interactions were examined using post-hoc ANOVAs with alpha levels adjusted for multiple comparisons using the Bonferroni procedure (Winer et al. 1991).

For Experiments 2-4, analysis began with an ANOVA for each measure (startle, PPI). Alpha was set at $p<.05$. Newman Keuls post-hoc tests were used to compare means when significant interactions (Experiments 1 and 4) or main effects (Experiments 2 and 3) were found for PPI. When significant interactions were found for habituation, post-hoc ANOVAs were applied and alpha levels were adjusted using the Bonferroni procedure.

\section{RESULTS}

\section{Experiment 1: 1AKO and 1BKO Mice}

Prepulse Inhibition. 1BKO mice exhibited significantly higher PPI levels than WT mice (Figure 1a), as revealed by a $2 \times 2$ ANOVA assessing the effects of saline and $10 \mathrm{mg} / \mathrm{kg}$ RU24969 on WT and 1BKO mice and yielding a main effect of genotype $[\mathrm{F}(1,23)=8.73, p<.01]$. A main effect of prepulse intensity was observed in every analysis for all experiments, confirming the normal relationship in which PPI levels increase with increasing prepulse intensities.

Treatment with $10 \mathrm{mg} / \mathrm{kg}$ of RU24969 decreased PPI across WT and $1 \mathrm{AKO}$ mice. This result was confirmed by an ANOVA collapsing for prepulse intensity and yielding a main effect of drug $[\mathrm{F}(1,18)=6.07, p<.03]$. 


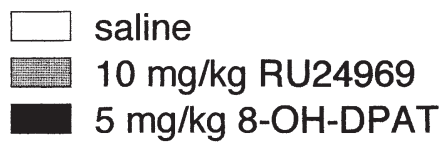

a.

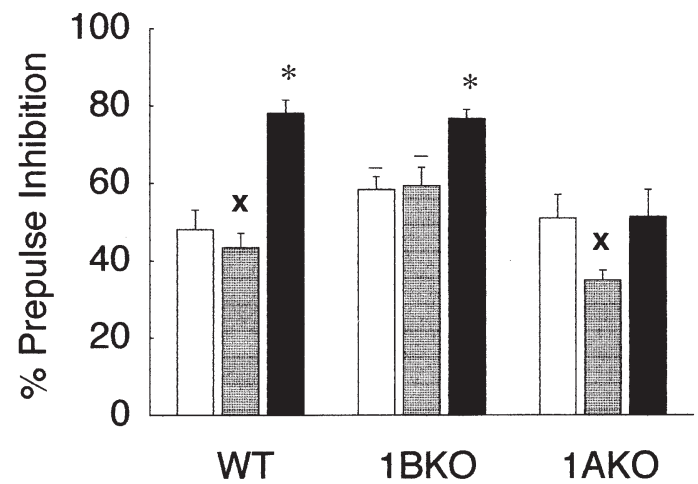

b.

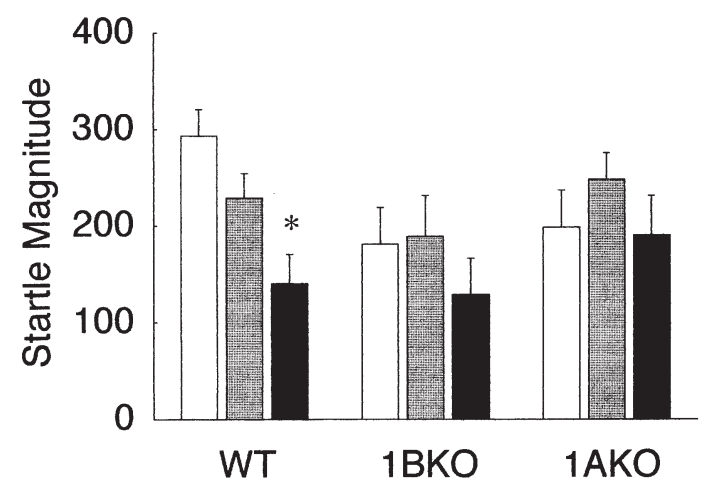

Figure 1. RU24969 decreases PPI in WTs and 1AKOs and 8-OH-DPAT increases PPI in WTs and 1BKOs. (a) PPI is shown collapsed across prepulse intensity for WT $(n=10)$, $1 \mathrm{AKO}(n=19)$, and $1 \mathrm{BKO}(n=15)$ mice treated with saline, $10 \mathrm{mg} / \mathrm{kg}$ RU24969, and $5 \mathrm{mg} / \mathrm{kg}$ 8-OH-DPAT. Values are means \pm SEM. An asterisk $\left({ }^{*}\right)$ indicates a significant difference from saline within the same genotype. A letter " $x$ " reflects the main effect for RU24969 to decrease PPI across WT and $1 \mathrm{AKO}$ mice. A dash (-) reflects the main effect for $1 \mathrm{BKO}$ mice to exhibit higher PPI levels than WT mice across treatment with saline and RU24969. (b) Average startle reactivity for blocks 2 and 3 is shown.

8-OH-DPAT treatment increased PPI in both WT and $1 \mathrm{BKO}$ mice. Analysis yielded a main effect of drug $[\mathrm{F}(1,23)=82.84, p<.0001]$, and an interaction of genotype $\times$ drug $[\mathrm{F}(1,23)=4.77, p<.04]$. Two post-hoc ANOVAs comparing the effects of saline and 8-OH-DPAT in either WT $[\mathrm{F}(1,9)=36.81, p<.0005]$ or $1 \mathrm{BKO}$ mice $[\mathrm{F}(1,14)=41.77, p<.0001]$ found a main effect of drug

8-OH-DPAT treatment increased PPI in WT, but not $1 \mathrm{AKO}$ mice. An ANOVA assessing the effects of saline and $5 \mathrm{mg} / \mathrm{kg} 8-\mathrm{OH}-\mathrm{DPAT}$ in WT and $1 \mathrm{AKO}$ mice yielded a main effect of drug $[\mathrm{F}(1,18)=22.04, p<.0005]$ and an interaction of genotype $\times$ drug $[\mathrm{F}(1,18)=20.65, p<$ .0005]. A post-hoc ANOVA comparing the effects of saline and 8-OH-DPAT in WT mice yielded a main effect of $\operatorname{drug}[\mathrm{F}(1,9)=36.81, p<.005]$. Another post-hoc ANOVA comparing 8-OH-DPAT-treated WT and $1 \mathrm{AKO}$ mice revealed a main effect of genotype $[\mathrm{F}(1,18)=13.44, p<$ .005], indicating that 8-OH-DPAT-treated WT mice had higher PPI levels than 8-OH-DPAT-treated 1AKO mice.

Startle Reactivity. 8-OH-DPAT treatment significantly decreased averaged blocks 2 and 3 startle reactivity in WT mice (Figure 1b). Additionally, both salinetreated $1 \mathrm{AKO}$ and $1 \mathrm{BKO}$ mice showed trends for reduced startle reactivity compared to saline-treated WT mice. The ANOVA assessing the effects of saline and $10 \mathrm{mg} /$ $\mathrm{kg}$ RU24969 on WT and 1AKO mice yielded a genotype $\times$ drug interaction $[\mathrm{F}(1,18)=12.63, p<.005]$. In addition, the ANOVA assessing the effects of saline and 5 $\mathrm{mg} / \mathrm{kg}$ 8-OH-DPAT on WT and 1BKO mice yielded a main effect of drug $[\mathrm{F}(1,23)=36.5, p<.0001]$ and $a$ genotype $\times$ drug interaction $[\mathrm{F}(1,23)=8.82, p<.01]$. Likewise, the ANOVA comparing the effects of saline and 8-OH-DPAT on WT and $1 \mathrm{AKO}$ mice yielded a main effect of drug $[\mathrm{F}(1,18)=38.72, p<.0001]$ and $a$ genotype $\times$ drug interaction $[\mathrm{F}(1,18)=31.19, p<$ .0001]. Two post-hoc ANOVAs confirmed a trend for a main effect of genotype in saline-treated WT and $1 \mathrm{BKO}$ mice $[\mathrm{F}(1,23)=4.99, p=.04, \alpha=.0125]$ and salinetreated $\mathrm{WT}$ and $1 \mathrm{AKO}$ mice $[\mathrm{F}(1,18)=4.40, p=.05, \alpha=$ .0125]. A third post-hoc ANOVA confirmed that 8-OHDPAT-treatment decreased startle reactivity in WT mice by yielding a main effect of drug $[\mathrm{F}(1,9)=55.0, p<$ $.0001]$. 1BKO mice $(23.0 \pm 0.7 \mathrm{~g})$ weighed significantly more than both WT $(19.2 \pm 0.4 \mathrm{~g})$ and $1 \mathrm{AKO}(20.3 \pm 0.9 \mathrm{~g})$ mice, which did not differ from one another. However, these small differences in average weight should not have affected startle values.

Treatment with 8-OH-DPAT and RU24969 decreased block 1 startle reactivity in WT mice, and both saline-treated $1 \mathrm{AKO}$ and $1 \mathrm{BKO}$ mice showed trends for reduced block 1 startle magnitude relative to WT mice (Figure 2). All four $2 \times 2$ ANOVAs evaluating the effects of genotype and drug on block 1 startle reactivity found significant main effects of drug, and genotype $\times$ drug interactions: the ANOVA assessing the effects of saline and 8-OH-DPAT on WT and $1 \mathrm{AKO}$ mice $[\mathrm{F}(1,18)=$ $26.60, p<.0001]$; the ANOVA assessing the effects of saline and RU24969 on WT and $1 \mathrm{AKO}$ mice $[\mathrm{F}(1,18)=$ 11.94, $p<.005]$; the ANOVA assessing the effects of saline and RU24969 on WT and 1BKO mice $[F(1,23)=10.26$, $p<.005]$; and the ANOVA assessing the effects of saline and $8-\mathrm{OH}-\mathrm{DPAT}$ on $\mathrm{WT}$ and $1 \mathrm{BKO}$ mice $[\mathrm{F}(1,23)=7.27$, $p=.0129$, (a trend)]. Two post-hoc ANOVAs confirmed with main effects of drug that 8-OH-DPAT $[\mathrm{F}(1,9)=$ 29.20, $p<.0005]$ and RU24969 [F(1,9) = 16.64, $p<.005]$ decreased startle reactivity in WT mice. Two additional post-hoc ANOVAs confirmed trends for $1 \mathrm{AKO}$ mice $[\mathrm{F}(1,18)=3.63, p=.07, \alpha=.0125]$ and $1 \mathrm{BKO}$ mice $[\mathrm{F}(1,23)=4.51, p=.04, \alpha=.0125]$ to exhibit reduced startle magnitude relative to WT mice. 


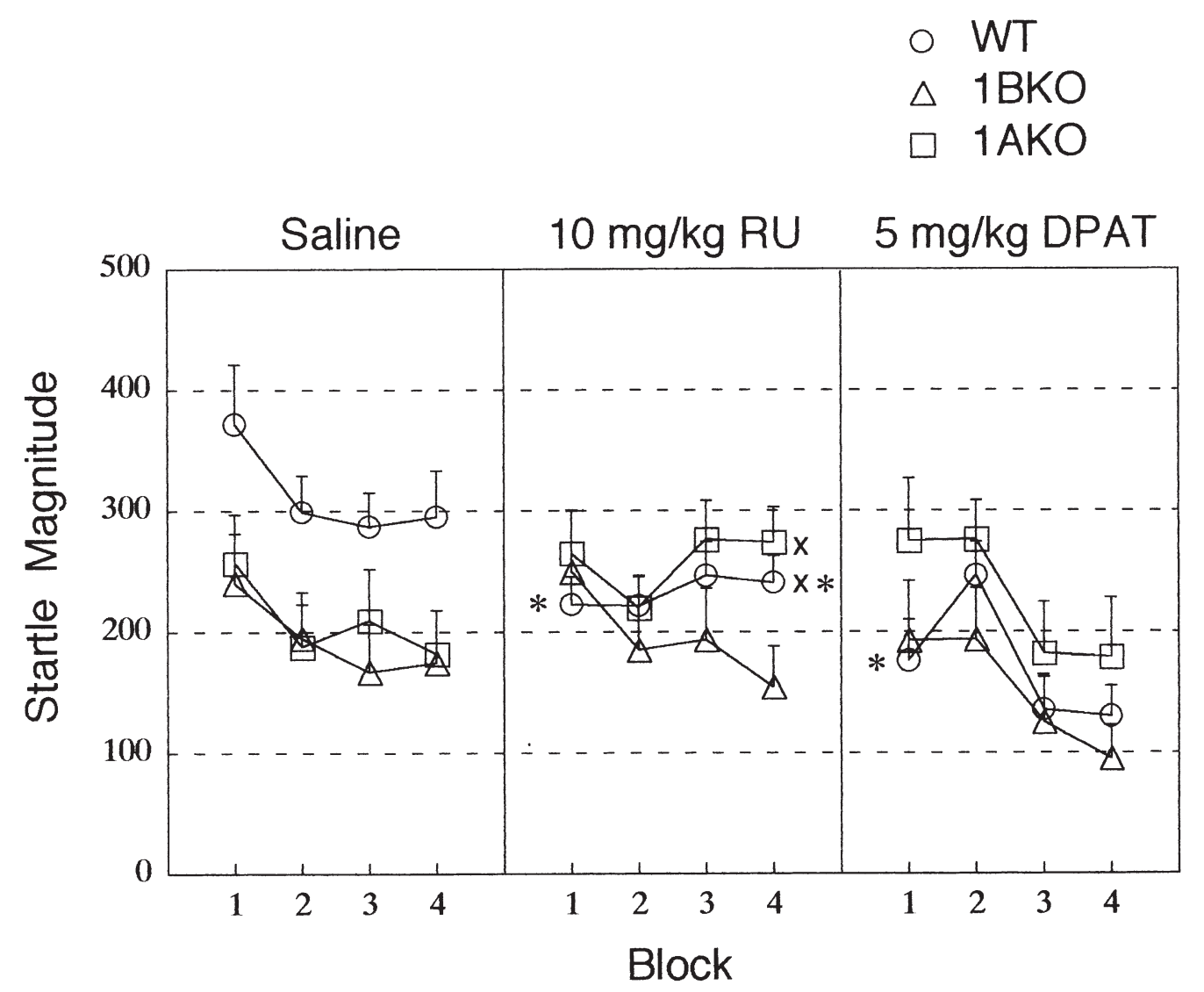

Figure 2. RU24969 decreases habituation in WTs and 1AKOs, but not 1BKOs. Startle reactivity is shown at each block for WT $(n=10), 1 \mathrm{AKO}(n=10)$, and 1BKO $(n=15)$ mice treated with saline, $10 \mathrm{mg} / \mathrm{kg}$ RU24969, and $5 \mathrm{mg} / \mathrm{kg} 8-\mathrm{OH}-\mathrm{DPAT}$. Values are means \pm SEM. An asterisk $\left(^{*}\right)$ indicates a significant difference from saline within the same genotype. A letter " $x^{\prime \prime}$ reflects the main effect for RU24969 to decrease habituation across WT and 1AKO mice. Symbols for block 1 values indicate differences in initial startle reactivity; symbols for block 4 values indicate differences in habituation.

Habituation. Habituation was not altered in any group of mice by $5 \mathrm{mg} / \mathrm{kg} 8$-OH-DPAT (Figure 2). The two ANOVAs assessing the effects of saline and $5 \mathrm{mg} /$ $\mathrm{kg} 8-\mathrm{OH}-\mathrm{DPAT}$ in the different genotypes yielded no interactions of genotype or drug with block.

Treatment with $10 \mathrm{mg} / \mathrm{kg}$ RU24969 decreased habituation across WT and $1 \mathrm{AKO}$ mice. The $2 \times 2 \times 4$ ANOVA assessing the effects of saline and $10 \mathrm{mg} / \mathrm{kg}$ RU24969 in WT and 1AKO mice revealed a significant drug $\times$ block interaction $[\mathrm{F}(3,54)=8.56, p<.0001]$.

RU24969-treatment decreased habituation in WT, but not $1 \mathrm{BKO}$ mice. The ANOVA assessing the effects of saline and $10 \mathrm{mg} / \mathrm{kg}$ RU24969 in WT and 1BKO mice revealed a trend for a genotype $\times$ drug $\times$ block interaction $[\mathrm{F}(3,69)=2.46, p=.069]$. Post-hoc ANOVAs were based on this trend and the a priori hypothesis derived from previous studies of $5-\mathrm{HT}_{1 \mathrm{~B}}$ receptor influences on habituation (Dulawa et al. 1997). The post-hoc $2 \times 4$ ANOVA assessing the effects of saline and RU24969 on habituation in WT mice revealed an interaction of drug $\times$ block $[\mathrm{F}(3,27)=4.82, p<.01]$, confirming that RU24969 decreased habituation in WT mice. However, the posthoc ANOVA assessing their effects in 1BKO mice found no drug $\times$ block interaction, confirming that RU24969 had no effect on habituation in 1BKO mice. Finally, a post-hoc ANOVA assessing habituation in RU24969treated WT and 1BKO mice yielded a significant genotype $\times$ block interaction $[\mathrm{F}(3,69)=5.89, p<.001]$ confirming that RU24969-treated WT mice exhibited reduced habituation compared to RU24969-treated 1BKO mice.

\section{Experiment 2: Flesinoxan}

Prepulse Inhibition. A $3 \times 4$ ANOVA revealed a main effect of flesinoxan $[\mathrm{F}(3,20)=6.08, p<.005]$, and a drug $\times$ prepulse intensity interaction $[\mathrm{F}(6,40)=5.99, p<$ .0005]. Newman Keuls post-hoc tests indicated that 10 $\mathrm{mg} / \mathrm{kg}$ flesinoxan increased PPI relative to all other doses at the six and $12 \mathrm{~dB}$ prepulse intensities (Figure 3).

Startle Reactivity. Neither block 1 nor averaged blocks 2 and 3 startle reactivity was altered by any dose of flesinoxan.

Habituation. The effects of flesinoxan on habituation in intact $129 \mathrm{~Sv}$ mice were assessed with a $4 \times 4$ ANOVA. A significant interaction of drug $\times$ block was 

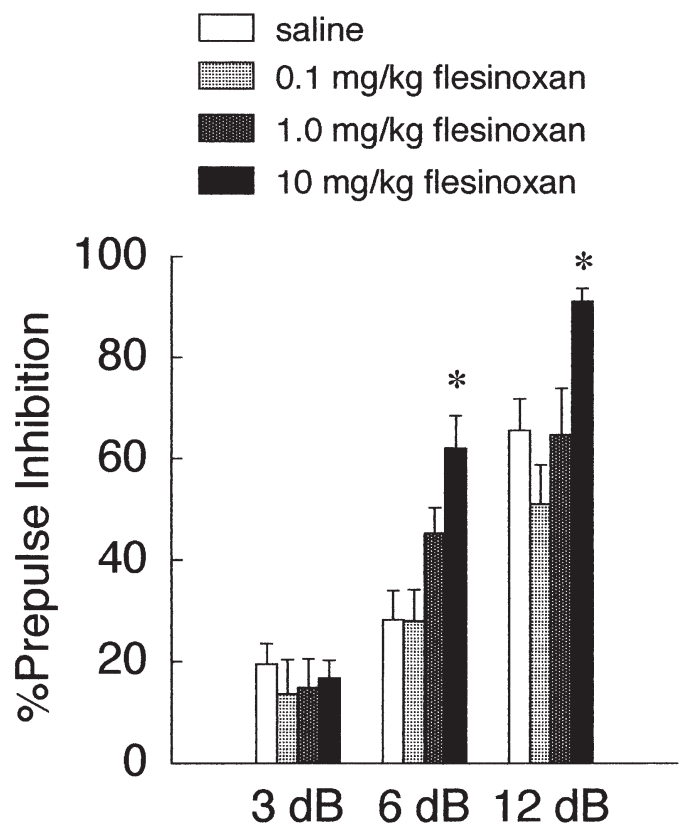

Figure 3. Flesinoxan increases PPI. PPI is shown for intact 129Sv mice receiving $0,0.1,1$, or $10 \mathrm{mg} / \mathrm{kg}$ flesinoxan $(n=6$ per group). Values are means \pm SEM. An asterisk $\left(^{*}\right)$ indicates a significant difference from all other doses at the same prepulse intensity.

found $[F(9,60)=2.33, p<.03]$. However, this interaction resulted from large variations in block two and three values, and not from differences in habituation across all four blocks.

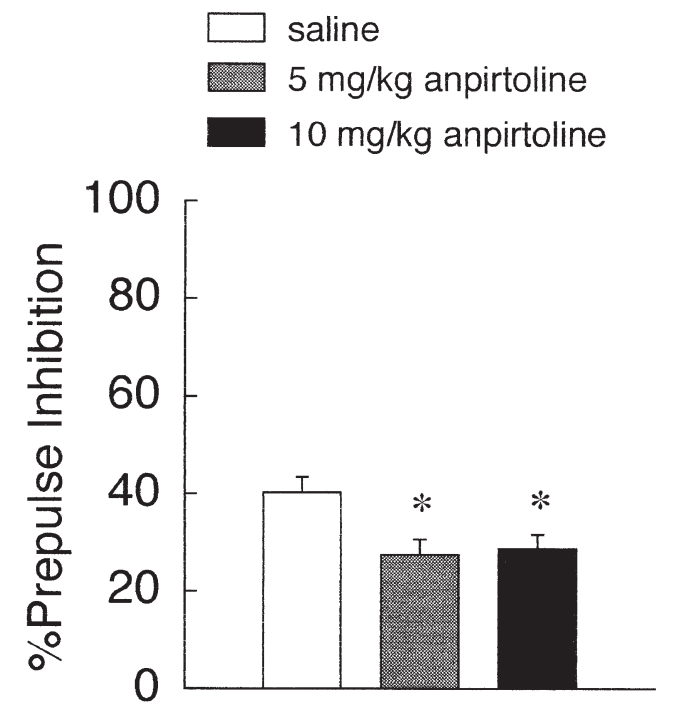

Figure 4. Anpirtoline decreases PPI. PPI is shown collapsed across prepulse intensity for intact $129 \mathrm{~Sv}$ mice receiving 0,5 , or $10 \mathrm{mg} / \mathrm{kg}$ anpirtoline ( $n=10$ per group). Values are means \pm SEM. An asterisk $\left({ }^{*}\right)$ indicates a significant difference from saline.

\section{Experiment 3: Anpirtoline}

Prepulse Inhibition. A one-way ANOVA collapsing across prepulse intensity revealed a main effect of drug $[\mathrm{F}(2,27)=5.90, p<.01]$. Newman Keuls post-hoc tests indicated that 5 and $10 \mathrm{mg} / \mathrm{kg}$ anpirtoline decreased PPI relative to saline (Figure 4 ).

Startle Reactivity. Neither block 1 nor averaged blocks 2 and 3 startle reactivity was altered by any dose of anpirtoline.

Habituation. A $3 \times 4$ ANOVA evaluated the effects of anpirtoline on habituation. A trend for a drug $\times$ block interaction was found $[\mathrm{F}(6,81)=1.73, p=.12]$, suggesting that anpirtoline reduces habituation (Figure 5). Posthoc ANOVAs were based on this trend and the a priori hypothesis that the $5-\mathrm{HT}_{1 \mathrm{~B}}$ receptor influences habituation (Dulawa et al. 1997). Post-hoc ANOVAs revealed trends for $5 \mathrm{mg} / \mathrm{kg}[\mathrm{F}(3,54)=1.97, p=.13]$ and $10 \mathrm{mg} /$ $\mathrm{kg}[\mathrm{F}(3,54)=1.96, p=.13]$ anpirtoline to decrease habituation relative to saline.

\section{Experiment 4: 1BKO Mice and Anpirtoline}

Prepulse Inhibition. A $2 \times 2$ ANOVA collapsing across prepulse intensity revealed a main effect of genotype $[\mathrm{F}(1,16)=6.69, p<.02]$ and a trend for a genotype $\times$ drug interaction $[\mathrm{F}(1,16)=3.32, p=.087]$. Newman Keuls post-hoc tests indicated that WT mice treated with $5 \mathrm{mg} / \mathrm{kg}$ anpirtoline had lower PPI levels than all other groups of mice. Thus, anpirtoline disrupted PPI in WT but not $1 \mathrm{BKO}$ mice (Figure 6).

Startle Reactivity. A trend for a main effect of genotype for averaged blocks 2 and 3 startle reactivity $[\mathrm{F}(1,16)=4.02, p=.06]$ was indicated by ANOVA. Newman Keuls post-hoc tests did not find any differences between means. 1BKO mice (23.4 $\pm 0.7 \mathrm{~g})$ weighed significantly more than WT mice $(20.3 \pm 0.9 \mathrm{~g})$, however this average difference of $3.1 \mathrm{~g}$ should not have affected startle values.

ANOVA also indicated a trend for a main effect of genotype for block 1 startle reactivity $[\mathrm{F}(1,16)=3.66, p=.07]$. No differences between genotypes were indicated by Newman Keuls post-hoc tests.

Habituation. The $2 \times 2 \times 4$ ANOVA assessing the effects of saline and $5 \mathrm{mg} / \mathrm{kg}$ anpirtoline in WT and $1 \mathrm{BKO}$ mice found no interactions of genotype or drug with block. Thus, neither genotype nor anpirtoline had effects on habituation.

\section{DISCUSSION}

The present results indicate that the activation of 5- $\mathrm{HT}_{1 \mathrm{~A}}$ receptors increases PPI, whereas the activation of $5-\mathrm{HT}_{1 \mathrm{~B}}$ 


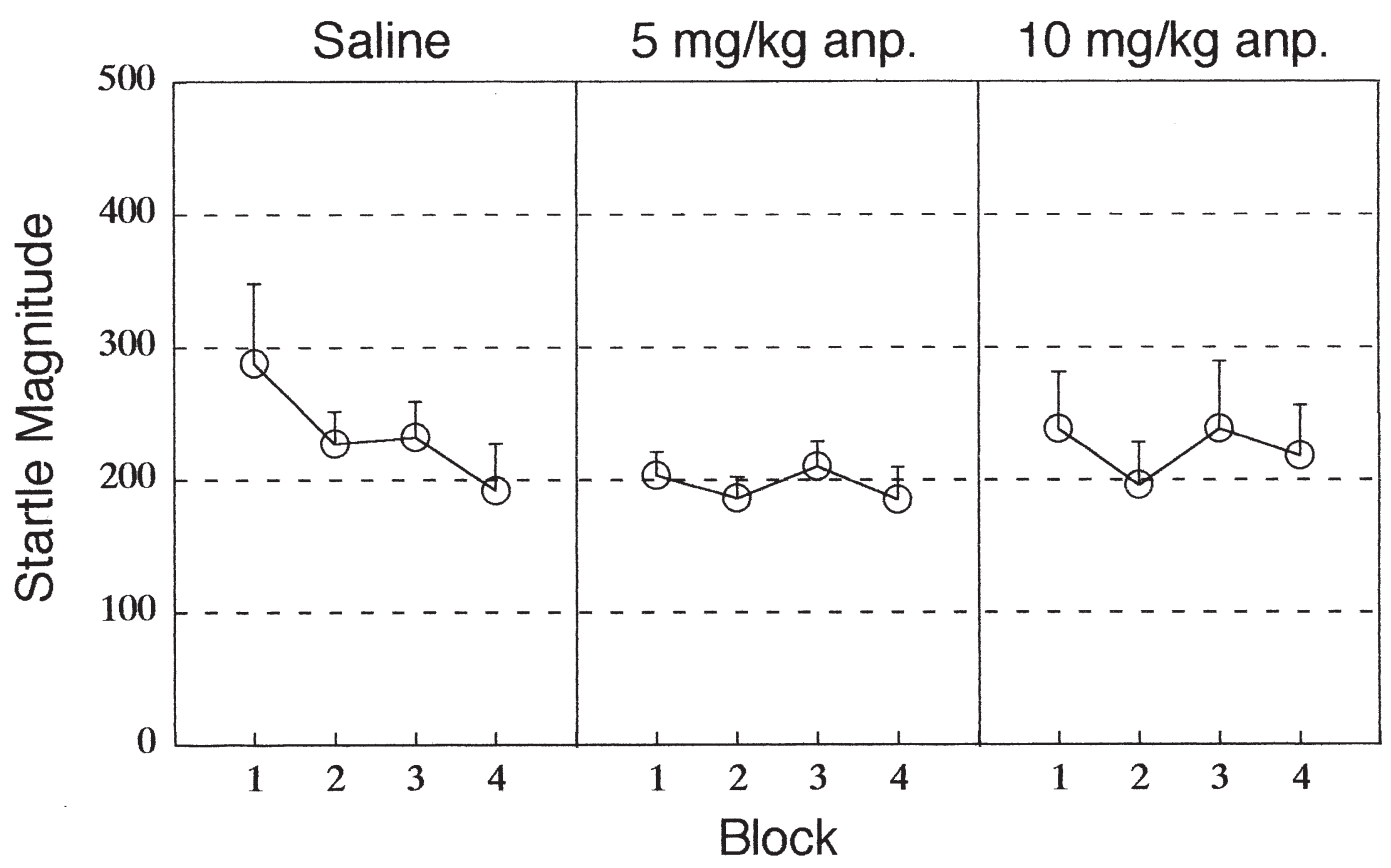

Figure 5. Anpirtoline decreases habituation. Startle reactivity is shown at each block for intact $129 \mathrm{~Sv}$ mice treated with 0,5 , or $10 \mathrm{mg} / \mathrm{kg}$ anpirtoline $(n=10$ per group). Values are means \pm SEM.

receptors decreases both PPI and habituation in mice. The $5-\mathrm{HT}_{1 \mathrm{~A}}$ agonist 8-OH-DPAT increased PPI in WT and $1 \mathrm{BKO}$, but not $1 \mathrm{AKO}$ mice, whereas the $5-\mathrm{HT}_{1 \mathrm{~A} / 1 \mathrm{~B}}$ agonist RU24969 decreased both PPI and habituation in WT and $1 \mathrm{AKO}$, but not $1 \mathrm{BKO}$ mice. Furthermore, the $5-\mathrm{HT}_{1 \mathrm{~B}}$ agonist anpirtoline decreased PPI in WT,
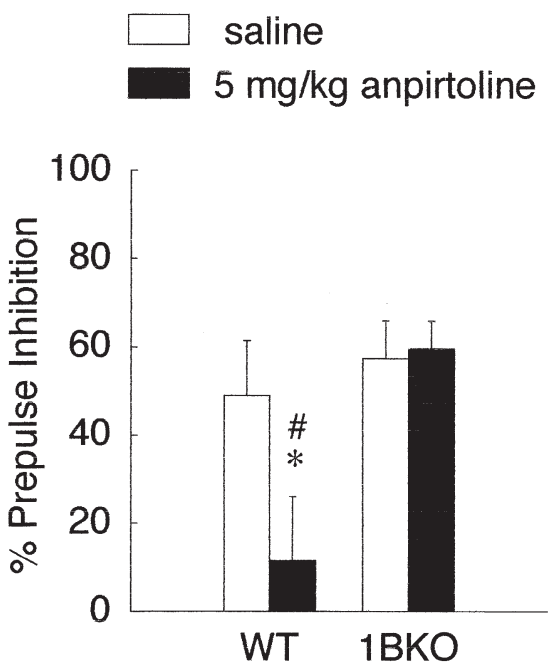

Figure 6. Anpirtoline decreases PPI in WT, but not 1BKOs. PPI is shown collapsed across prepulse intensity for WT $(n=$ $10)$ and $1 \mathrm{BKO}(n=10)$ mice receiving 0 or $5 \mathrm{mg} / \mathrm{kg}$ anpirtoline. Values are means \pm SEM. An asterisk $(*)$ indicates a significant difference from saline within the same genotype. A pound sign (\#) indicates a significant difference from WT mice within the same treatment group. but not $1 \mathrm{BKO}$ mice. Consistent with these results, the $5-\mathrm{HT}_{1 \mathrm{~A}}$ agonist flesinoxan increased PPI, whereas anpirtoline decreased both PPI and habituation in intact 129Sv mice. The opposite roles of 5- $\mathrm{HT}_{1 \mathrm{~A}}$ and $5-\mathrm{HT}_{1 \mathrm{~B}}$ receptors in modulating PPI are consistent with their opposite effects on a number of other behavioral responses (Zhuang et al. 1999).

No phenotypic difference in PPI was observed in $1 \mathrm{AKO}$ mice, although a small increase in PPI was found in $1 \mathrm{BKO}$ mice (Figure 1). The phenotypic increase in PPI observed in 1BKO mice is consistent with earlier reports (Dulawa et al. 1997) and the present findings that RU24969 and anpirtoline decrease PPI in WT, but not 1BKO mice. The small phenotypic increase in PPI may result from lack of the normal activation of $5-\mathrm{HT}_{1 \mathrm{~B}}$ receptors by endogenous serotonin. $1 \mathrm{AKO}$ mice did not show a phenotypic decrease in PPI, which might have been expected, because 8-OH-DPAT and flesinoxan increase PPI. Hence, under non-challenged conditions, the endogenous serotonergic tone may be insufficient to modulate PPI via $5-\mathrm{HT}_{1 \mathrm{~A}}$ receptors, although sufficient to do so via $5-\mathrm{HT}_{1 \mathrm{~B}}$ receptors. Alternatively, developmental compensations specific to the $1 \mathrm{AKO}$ mice may obscure the effects of absence of the receptor on PPI.

In Experiment 1, a total of $5 \mathrm{mg} / \mathrm{kg}$ of 8-OH-DPAT increased PPI in WT and $1 \mathrm{BKO}$, but not $1 \mathrm{AKO}$ mice. The reduction in startle reactivity produced by $8-\mathrm{OH}-$ DPAT in WT mice is unlikely to be responsible for the increase in PPI, because 8-OH-DPAT increased PPI in 1BKO mice without significantly altering startle reactivity (Figure 1). Furthermore, $10 \mathrm{mg} / \mathrm{kg}$ of the selective 
5-HT $\mathrm{H}_{1 \mathrm{~A}}$ agonist flesinoxan increased PPI without altering startle reactivity (Figure 3). The PPI-increasing effects of 8-OH-DPAT and flesinoxan in mice are intriguing because $8-\mathrm{OH}-\mathrm{DPAT}$ and other $5-\mathrm{HT}_{1 \mathrm{~A}}$ agonists decrease PPI in rats (Rigdon and Weatherspoon 1992; Sipes and Geyer 1995). We previously observed that 8-OH-DPAT increases PPI in mice, and that this effect could be prevented by pretreatment with the $5-\mathrm{HT}_{1 \mathrm{~A}}$ antagonist WAY100,635 (Dulawa et al. 1998). However, 8-OH-DPAT and a number of 5- $\mathrm{HT}_{1 \mathrm{~A}}$ antagonists have some affinity for the 5- $\mathrm{HT}_{7}$ receptor (Tsou et al. 1994; Ying and Rusak 1997). Thus, the lack of effect of $8-\mathrm{OH}-$ DPAT on PPI in $1 \mathrm{AKO}$ mice provides evidence that the effects of $8-\mathrm{OH}-\mathrm{DPAT}$ on PPI are mediated by $5-\mathrm{HT}_{1 \mathrm{~A}}$ receptors and not $5-\mathrm{HT}_{7}$ receptors.

Treatment with $10 \mathrm{mg} / \mathrm{kg}$ RU24969 reduced PPI across WT and 1AKO, but not $1 \mathrm{BKO}$ mice. However, RU24969 appeared to decrease PPI more robustly in 1 AKO mice than in WT (Figure 1). This apparent difference may have resulted from the PPI-increasing effect of RU24969 at 5- $\mathrm{HT}_{1 \mathrm{~A}}$ receptors in WT mice. Consistent with this idea is the finding that the selective $5-\mathrm{HT}_{1 \mathrm{~B}}$ agonist anpirtoline produced a robust PPI disruption in WT, but not $1 \mathrm{BKO}$ mice (Figure 6). Thus, the present results indicate that the activation of $5-\mathrm{HT}_{1 \mathrm{~B}}$ receptors disrupts PPI more robustly than previously suggested.

Constitutive genetic manipulations can lead to compensatory changes that may influence the behavioral phenotype. Scearce et al. (1997) reported a 15\% increase in dopamine transporter binding in the dorsolateral striatum, a 20\% increase in dopamine D1 receptor binding in the anterior ventrolateral striatum, a 20\% decrease in serotonin transporter binding, and an increase in $\mathrm{D} 1$ receptor mRNA in whole striatum of $1 \mathrm{BKO}$ mice. Although autoradiographic analysis has not revealed changes in $5-\mathrm{HT}_{1 \mathrm{~A}}$ receptor binding in $1 \mathrm{BKO}$ mice (Hen, unpublished observations), the present findings might reflect some functional desensitization of $5-\mathrm{HT}_{1 \mathrm{~A}}$ receptors in $1 \mathrm{BKO}$ mice. For example, 8-OH-DPAT appeared to produce a less robust increase in PPI in 1BKO mice than in WT mice (Figure 1), which has been observed consistently (Dulawa et al. 1997). Although this result may represent a ceiling effect, there is also an absence of a 1A-effect (increased PPI) in 1BKO mice treated with RU24969. One might have expected to find a small increase in PPI due to the moderate affinity of RU24969 for the $5-\mathrm{HT}_{1 \mathrm{~A}}$ receptor; the $1 \mathrm{~A}$-effect can be observed when comparing the effect of RU24969 on PPI in WT and $1 \mathrm{AKO}$ mice. Some compensatory changes have also been reported in $1 \mathrm{AKO}$ mice. For example, 5- $\mathrm{HT}_{1 \mathrm{~B}}$ receptors may be upregulated (Ramboz et al. 1998), although there is little evidence for a behavioral consequence of this upregulation in the present experiments.

The activation of $5-\mathrm{HT}_{1 \mathrm{~A}}$ receptors increases PPI in mice (Dulawa et al. 1997, 1998), and decreases PPI in rats (Sipes and Geyer 1995; Rigdon and Weatherspoon
1992). Inconsistencies have also been reported regarding the effects of drugs on PPI in rats versus humans. For example, the serotonin releaser 3,4-methylenedioxymethamphetamine (MDMA or "ecstasy") decreases PPI in rats (Kehne et al. 1992; Mansbach et al. 1989; Vollenweider et al. 1999), but increases PPI in healthy humans (Vollenweider et al. 1999). In addition, MDMA decreases PPI in some substrains of 129 mice (Dulawa and Geyer 1996), but not in others (Dulawa et al. 1998). These conflicting results raise the question as to which rodent model will more closely resemble humans. Flesinoxan is currently being investigated as a potential antidepressant in humans (Baumann and Bertschy 1997; Grof et al. 1993). Thus, assessment of the effects of flesinoxan on PPI in humans might soon be possible. Because $5-\mathrm{HT}_{1 \mathrm{~A}}$ receptors have a similar distribution pattern in the mouse (Ramboz et al. 1998), the rat (Marcinkiewicz et al. 1984; Pompeiano et al. 1992), and humans (Pazos et al. 1987; Hoyer et al. 1986), unique distribution patterns are an unlikely reason for the species-specific effects of 8-OH-DPAT on PPI. A more plausible explanation is a difference in the balance of preand postsynaptic receptor signaling between species. Study of these differences could greatly improve our understanding of the neural circuits modulating these behaviors, and allow the selection of the most appropriate animal model for addressing specific hypotheses.

Trends were found for initial startle reactivity to be decreased in $1 \mathrm{AKO}$ and $1 \mathrm{BKO}$ mice relative to $\mathrm{WT}$, although there were no significant differences between groups (Figure 2). We previously observed a significant decrease in block 1 startle reactivity in $1 \mathrm{BKO}$ male mice, and no effect on block 1 startle reactivity in 1BKO female mice, all relative to WT mice (Dulawa et al. 1997). $1 \mathrm{AKO}$ mice have been reported to have increased anxiety (Ramboz et al. 1998; Parks et al. 1998; Heisler et al. 1998), whereas 1 BKO mice have somewhat decreased anxiety (Ramboz et al. 1998; Brunner and Hen 1997) in the same behavioral tests. Yet, a trend for decreased initial startle reactivity was observed in both $1 \mathrm{AKO}$ and $1 \mathrm{BKO}$ mice compared to WT mice. This discrepancy suggests that baseline startle reactivity may not be a sensitive measure of anxiety, or alternatively, that different neural circuits mediate different aspects of anxiety.

Startle habituation phenotypes were comparable in $\mathrm{WT}, 1 \mathrm{AKO}$, and $1 \mathrm{BKO}$ mice. However, $10 \mathrm{mg} / \mathrm{kg}$ RU24969 disrupted habituation in WT and 1AKO, but not 1BKO mice (Figure 2), consistent with an earlier report (Dulawa et al. 1997) assessing WT and 1BKO mice. This finding indicates that activation of $5-\mathrm{HT}_{1 \mathrm{~B}}$ receptors decreases habituation, and that $5-\mathrm{HT}_{1 \mathrm{~A}}$ receptors are not involved in the RU24969-induced decrease in habituation. This disruption of habituation was not confounded by significant differences in block 1 startle reactivity between RU24969-treated WT, 1AKO, or 1BKO mice. A trend for anpirtoline to disrupt habituation was 
also observed in intact 129Sv mice (Figure 5). Although anpirtoline did not alter habituation in WT mice in Experiment 4 , this discrepancy was probably due to the fact that three times as many intact mice were used in Experiment 3 (30 129Sv mice) as in Experiment 4 (10 WT ), and that startle responses show considerable variability. No changes in habituation resulted from flesinoxan or 8-OH-DPAT treatment in any group of mice, as reported with rats (Geyer and Tapson 1988). The lack of effect of 8-OH-DPAT in $1 \mathrm{AKO}$ mice suggests that $5-\mathrm{HT}_{7}$ receptors do not modulate habituation. Together, these findings indicate that $5-\mathrm{HT}_{1 \mathrm{~B}}$ but not $5-\mathrm{HT}_{1 \mathrm{~A}}$ receptors modulate habituation in mice.

Lack of the $5-\mathrm{HT}_{1 \mathrm{~A}}$ or $5-\mathrm{HT}_{1 \mathrm{~B}}$ receptor does not induce substantial changes in the expression of PPI or habituation. However, under drug-challenged conditions, 5- $\mathrm{HT}_{1 \mathrm{~B}}$ receptor activation decreases PPI and habituation, and $5-\mathrm{HT}_{1 \mathrm{~A}}$ receptor activation increases PPI. Because $5-\mathrm{HT}_{1 \mathrm{~A}}$ and $5-\mathrm{HT}_{1 \mathrm{~B}}$ receptors are important for the modulation of sensorimotor gating, future experiments using tissue-specific knockout manipulations (Stark et al. 1998) to examine their pre- and postsynaptic contributions to these behaviors are warranted.

\section{ACKNOWLEDGMENTS}

The authors acknowledge the generous gifts of flesinoxan from Solvay Pharma, and RU24969 from Roussel UCLAF. This work was supported by grants from the National Institute on Drug Abuse (R02DA02925 \& R01DA09862-01), the National Institute of Mental Health (NIMH) P01MH48126-06, the National Alliance for Research on Schizophrenia and Depression (NARSAD), and the U.S. Veterans Affairs VISN22 Mental Illness Research, Education, and Clinical Center. S.C. Dulawa was supported by a predoctoral NRSA from NIMH (F31-MH12249-01). C. Gross was supported by a grant from NIMH (F32MH12364-01). M.A. Geyer holds equity interest in San Diego Instruments, Inc.

\section{REFERENCES}

Baumann P, Bertschy G (1997): Long-term treatment of depression: Is there a use for depot antidepressants? Intl Clin Psychopharmacol 12:77-80

Bolino F, Di Michele V, Di Cicco L, Manna V, Daneluzzo E, Casacchia M (1994): Sensorimotor gating and habituation evoked by electro-cutaneous stimulation in schizophrenia. Biol Psychiatry 36:670-679

Boschert U, Amara DA, Segu L, Hen R (1994): The mouse 5-hydroxytryptamine $\mathrm{A}_{1 \mathrm{~B}}$ receptor is localized predominantly on axon terminals. Neuroscience 58:167-182

Braff DL, Stone C, Callaway E, Geyer MA, Glick I, Bali L (1978): Prestimulus effects on human startle reflex in normals and schizophrenics. Psychophysiology 15:339-343

Braff DL, Grillon C, Geyer MA (1992): Gating and habitua- tion of the startle reflex in schizophrenic patients. Arch Gen Psychiatry 49:206-215

Brunner D, Hen R (1997): Insights into the neurobiology of impulsive behavior from serotonin receptor knockout mice. In Stoff DM, Mann JJ (eds), The Neurobiology of Suicide: From the Bench to the Clinic. New York, New York Academy of Sciences, pp 81-105

Cadenhead KS, Geyer MA, Braff DL (1993): Impaired startle prepulse inhibition and habituation in patients with schizotypal personality disorder. Am J Psychiatry 180:1862-1870

Caine SB, Geyer MA, Swerdlow NR (1991): Carbachol infusion into the dentate gyrus disrupts sensorimotor gating of startle in the rat. Psychopharmacology 105:347354

Doods HN, Kalkman HO, De Jinge A, Thoolen MJMC, Wilffert B, Timmermans PBMWM, Van Zwieten PA (1985): Differential selectivities of RU 24969 and 8-OH-DPAT for the purported 5-HT1A and 5-HT1B binding sites. Correlation between 5-HT1A affinity and hypotensive activity. Eur J Pharm 112:363-370

Dulawa SC, Geyer MA (1996): Psychopharmacology of prepulse inhibition in mice. Chinese J Physiol 39:1-8

Dulawa SC, Hen R, Scearce-Levie K, Geyer MA (1997): Serotonin $_{1 \mathrm{~B}}$ receptor modulation of startle reactivity, habituation, and prepulse inhibition in wild type and serotonin $_{1 B}$ knockout mice. Psychopharmacology 132: 125-134

Dulawa SC, Hen R, Scearce-Levie K, Geyer MA (1998): Serotonin $_{1 \mathrm{~B}}$ receptor modulation of prepulse inhibition: Recent findings in wild type and $5-\mathrm{HT}_{1 \mathrm{~B}}$ knockout mice. Ann NY Acad Sci 861:79-84

Geyer MA, Tapson GS (1988): Habituation of tactile startle is altered by drugs acting on serotonin-2 receptors. Neuropsychopharmacology 1:135-147

Geyer MA, Braff DL (1982): Habituation of the blink reflex in normals and schizophrenic patients. Psychophysiology 19:1-6

Graham FK (1975): The more or less startling effects of weak prestimuli. Psychophysiology 12:238-248

Grof P, Joffe R, Kennedy S, Persad E, Syrotiuk J, Bradford D (1993): An open study of oral flesinoxan, a 5-HT1A receptor agonist, in treatment-resistant depression. Int Clin Psychopharm 8:167-172

Hamon M, Lanfumey L, El Mestikawy S, Boni C, Miquel MC, Bolanos F, Schechter L, Gozalan H (1990): The main features of central 5-HT1 receptors. Neuropsychopharmacology 3:349-360

Heisler LK, Chu HM, Brennan TJ, Danao JA, Bajwa P, Parsons LH, Tecott LH (1998): Elevated anxiety and antidepressant-like responses in serotonin 5-HT1A receptor mutant mice. Proc Natl Acad Sci USA 95:15049-15054

Hen R (1992): Of mice and flies: Commonalities among 5-HT receptors. Trends Pharmacol Sci 13:160-165

Hoyer D, Pazos A, Probst A, Palacios JM (1986): Serotonin receptors in the human brain. I. Characterization and autoradiographic localization of 5-HT1A recognition sites. Apparent absence of 5-HT1B recognition sites. Brain Res 376:85-96

Kehne JH, McCloskey TC, Taylor VL, Black CK, Fadayel GM, 
Schmidt CJ (1992): Effects of the serotonin releasers 3,4methylenedioxymethamphetamine (MDMA), 4-chloroamphetamine (PCA) and fenfluramine on acoustic and tactile startle reflexes in rats. J Pharmacol Exp Ther 260:78-89

Koch M (1996): The septohippocampal system is involved in prepulse inhibition of the acoustic startle response in rats. Behav Neurosci 110:468-477

Leishman DJ, Boeijinga PH, Galvan M (1994): Differential effects of centrally-active antihypertensives on 5-HT1A receptors in rat dorso-lateral septum, rat hippocampus and guinea-pig hippocampus. Br J Pharmacol 111:318-324

Mansbach RS, Geyer MA, Braff DL (1988): Dopaminergic stimulation disrupts sensorimotor gating in the rat. Psychopharmacol 94:507-514

Mansbach RS, Braff DL, Geyer MA (1989): Prepulse inhibition of the acoustic startle response is disrupted by N-ethyl-3,4-methylenedioxyamphetamine (MDEA) in the rat. Eur J Pharmacol 167:49-55

Marcinkiewicz M, Verge D, Gozlan H, Pichat L, Hamon M (1984): Autoradiographic evidence for the heterogeneity of 5-HT1 sites in the rat brain. Brain Res 291:159-163

Parks CL, Robinson PS, Sibille E, Shenk T, Toth M (1998): Increased anxiety of mice lacking the serotonin1A receptor. Proc Natl Acad Sci USA 95:10734-10739

Pazos A, Hoyer D, Dietl MM, Palacios JM (1988): Autoradiography of serotonin receptors. In Osborne NN, Hamon M (eds), Neuronal Serotonin. New York, Wiley, pp 507-543

Pazos A, Probst A, Palacios JM (1987): Serotonin receptors in the human brain. IV. Autoradiographic mapping of serotonin-1 receptors. Neuroscience 21:97-122

Phillips TJ, Hen R, Crabbe JC (1999): Complications associated with genetic background effects in research using knockout mice. Psychopharmacology 147:5-7

Pompeiano M, Palacios JM, Mengod G (1992): Distribution and cellular localization of mRNA coding for 5-HT1A receptor in the rat brain: Correlation with receptor binding. J Neurosci 12:440-453

Ramboz S, Oosting R, Amara DA, Kung HF, Blier P, Mendelsohn M, Mann JJ, Brunner D, Hen R (1998): Serotonin receptor 1A knockout: An animal model of anxietyrelated disorder. Proc Natl Acad Sci USA 95:14476-14481

Rigdon GC, Weatherspoon J (1992): $5 \mathrm{HT}_{1 \mathrm{~A}}$ receptor agonists block prepulse inhibition of the acoustic startle reflex. J Pharmacol Exp Ther 263:486-493

Saudou F, Amara DA, Dierich A, LeMeur M, Ramboz S, Segu L, Buhot MC, Hen R (1994): Enhanced aggressive behavior in mice lacking $5-\mathrm{HT}_{1 \mathrm{~B}}$ receptor. Science 265:1875-1878

Scearce K, Kassir S, Lucas J, Castanon N, Segu L, Arango V, Hen R (1997): Dopaminergic compensations in knockout mice lacking the serotonin $1 \mathrm{~B}$ receptor. Abstr Soc Neurosci 23:202.2
Schlicker E, Werner U, Hamon M, Nickel B, Szelenyi I, Gothert M. (1992): Anpirtoline, a novel, highly potent 5-HT1B receptor agonist with antinociceptive/antidepressant-like actions in rodents. $\mathrm{Br} \mathrm{J}$ Pharmacol 105:732-738

Schoeffter P, Hoyer D (1988): Centrally acting hypotensive agents with affinity for 5-HT1A binding sites inhibit forskolin-stimulated adenylate cyclase activity in calf hippocampus. Br J Pharmacol 95:975-985

Sills MA, Wolfe BB, Frazer A (1984): Determination of selective and nonselective compounds for the 5-HT1A and 5-HT1B receptor subtypes in rat frontal cortex. J Pharmacol Exp Ther 231:480-487

Sipes TA, Geyer MA (1995): 8-OH-DPAT disruption of prepulse inhibition in rats: Reversal with (+)WAY 100,135 and localization of site of action. Psychopharmacology 117:41-48

Sipes TE, Geyer MA (1997): DOI disrupts prepulse inhibition of startle in rats via 5-HT2A receptors in the ventral pallidum. Brain Res 761:97-104

Stark KL, Oosting R, Hen R (1998): Novel strategies to probe the functions of serotonin receptors. Biol Psychiatry 44:163-168

Swerdlow NR (1995): Serotonin, obsessive compulsive disorder and the basal ganglia. Int Rev Psychiatry 7:115129

Swerdlow NR, Braff DL, Geyer MA (1990): GABAergic projection from nucleus accumbens to ventral pallidum mediates dopamine-induced sensorimotor gating deficits of acoustic startle in rats. Brain Res 532:146-150

Swerdlow NR, Caine SB, Braff DL, Geyer MA (1992): Neural substrates of sensorimotor gating of the startle reflex: Preclinical findings and their implications. J Psychopharmacol 6:176-190

Thorpe WH (1956): Learning and Instinct in Animals. Cambridge MA, Harvard University Press

Tsou AP, Kosaka A, Bach C, Zuppan P, Yee C, Tom L, Alvarez R, Ramsey S, Bonhaus DW, Stefanich E, Jakeman L, Eglen RM, Chan HW (1994): Cloning and expression of a 5-hydroxytryptamine7 receptor positively coupled to adenylyl cyclase. J Neurochem 63:456-464

Vollenweider FX, Remensberger S, Hell D, Geyer MA (1999): Opposite effects of 3,4-methylenedioxymethamphetamine (MDMA) on sensorimotor gating in rats versus healthy humans. Psychopharmacology 143:365-372

Winer BJ, Brown DR, Michels KM (1991): Statistical Principles in Experimental Design. New York, McGraw-Hill, Inc

Ying SW, Rusak B (1997): 5-HT7 receptors mediate serotonergic effects on light-sensitive suprachiasmatic nucleus neurons. Brain Res 755:246-254

Zhuang X, Gross C, Santarelli L, Compan V, Trillat A-C, Hen $R$ (1999): Altered emotional states in knockout mice lacking 5-HT1A or 5-HT1B receptors. Neuropsychopharmacology 21:52S-60S 